Article

\title{
Montmorillonite K10-Catalyzed Solvent-Free Conversion of Furfural into Cyclopentenones
}

\author{
Sonia Bonacci ${ }^{1}$, Monica Nardi ${ }^{1, *}$, Paola Costanzo ${ }^{1}\left(\mathbb{D}\right.$, Antonio De Nino ${ }^{2}$, \\ Maria Luisa Di Gioia ${ }^{3}$, Manuela Oliverio ${ }^{1}{ }^{10}$ and Antonio Procopio ${ }^{1}$ \\ 1 Dipartimento di Scienze della Salute, Università Magna Græcia, Viale Europa, Germaneto, \\ 88100 Catanzaro CZ, Italy; s.bonacci@unicz.it (S.B.); pcostanzo@unicz.it (P.C.); m.oliverio@unicz.it (M.O.); \\ procopio@unicz.it (A.P.) \\ 2 Dipartimento di Chimica, Università della Calabria Cubo 12C, 87036 Arcavacata di Rende CS, Italy; \\ antonio.denino@unical.it \\ 3 Dipartimento di Farmacia e Scienze della Salute e della Nutrizione, Edificio Polifunzionale, \\ Università della Calabria, Arcavacata di Rende, 87030 Cosenza, Italy; ml.digioia@unical.it \\ * Correspondence: monica.nardi@unicz.it; Tel.: +39-0984-492-850
}

Received: 23 February 2019; Accepted: 21 March 2019; Published: 26 March 2019

\begin{abstract}
A simple and eco-friendly montmorillonite K10 (MK10)-catalyzed method for the synthesis of cyclopentenone derivatives from biomass-produced furfural has been developed. The versatility of this protocol is that the reactions were performed under solvent-free conditions and in a short reaction time under heterogeneous catalysis. Montmorillonite K10 is mostly explored as a heterogeneous catalyst since it is inexpensive and environmentally friendly.
\end{abstract}

Keywords: heterogeneous catalysis; montmorillonite; furfural; cyclopentenones

\section{Introduction}

In the last few decades, the use of heterogeneous catalysis has become a promising field in chemical synthesis, especially in industrial applications [1]. From an economic point of view, the tendency to use heterogeneous acid catalysis in the industrial field derives from their intrinsic stability, ease of recovery, separation and recycling minimizing waste contamination. On the other hand, the use of volatile and dangerous solvents in the chemical industry represents a risk for the environment and human health [2-6], so that the necessity for clean processes, in which energy, waste and costs are reduced, is of general concern [7].

Different studies have encouraged the use of unconventional methods or "green" solvents [8], principally water [8-15], ionic liquids [16-20], deep eutectic solvents [21-24], or bio-solvents [25-30], but the use of solvent-free conditions [31-36] is certainly the best choice to conduct eco-sustainable chemical procedures. A solvent-free reaction can be performed by using the reactants alone, or incorporating them in solid supports simplifying the experimental and work-up procedures, and considerably lowering the environmental impact. These would be particularly important in industrial manufacturing, where, in the last few decades, the use of microwave heating among others [37-40], was proposed in solvent-free chemical processes catalyzed by solid Lewis acids as a useful method for increasing the reaction rate, simplifying the work and improving the yield [41-44].

The Pollution Prevention Act of 1990 was endorsed to raise interest in pollution prevention, and to encourage the design of environmentally benign processes and products.

Lowering the environmental impact of industrial activities is particularly important for the pharmaceutical industry, as it is very often indicated as the principal source of environmental pollution [45]. In recent years, the use of renewable sources or waste materials as starting products has become 
very important for obtaining useful pharmaceutical synthons [46-48]. In this context, furfural is an important biomass compound that is derived and used to synthesize different bio-products [49]. The cyclopentenone derivatives in fact represent a vast variety of bioactive molecules. Particularly, the chiral 2,4-disubstituted cyclopentenones as prostaglandins have anti-inflammatory [50], anticancer [51], and antiviral activities [52,53], and the presence of an $\alpha, \beta$-unsaturated carbonyl group is important for the biological activity of these compounds. The cyclization rearrangement can be realized by different Lewis acids as metallic compounds [54], triflate [55-57], and metal chloride [58] in ionic liquids [59], or by using green media as water [60] or deep eutectic solvents [61].

Solid supports have gained interest in organic synthesis for their extremely versatile properties, thermal stability, and low cost.

Recyclable heterogeneous catalysts have been extensively experimented, but their activities are generally lower with respect to those of homogeneous catalysts, as the exposure degree of the active site to the reactants is lower. Lanthanide chloride immobilized on silica as $\mathrm{ErCl}_{3} \cdot 6 \mathrm{H}_{2} \mathrm{O}[62,63]$ was proposed for the preparation of diaminocyclopent-2-enones from furfural, but the procedure involved the use of organic solvents to obtain a selectivity of above $83 \%$. Recently, a metal-organic framework (MOF) showed a higher activity than the homogeneous catalyst, but the system conditions under which the reaction occurred, such as the use of organic solvents under an $\mathrm{N}_{2}$ atmosphere, were crucial in determining the course of the performance [64].

MK10 is considered to be a very interesting clay catalyst $[65,66]$ because it offers several advantages compared to other solid supports [67]. It might act as a general Brønsted or Lewis acid, and it is considered to be an inexpensive green catalyst [68] since it prevents waste, and it is reusable and safe to handle. In fact, MK10 can be simply recovered by filtration and used in a one-pot process under solvent-free conditions and microwave or ultrasound irradiation [69].

Taking into account the stability and catalytic activity of MK10, and considering our knowledge in developing eco-friendly reactions for the synthesis of pharmaceutical compounds [70-78], we decided to test the MK10 as catalyst in the cyclization of the furfural for the synthesis of bifunctionalized cyclopentenones. The catalytic process showed high conversion and selectivity under MW irradiation. It is scalable and can be considered a promising renewable method for the production of bio-derived compounds in the pharmaceutical industry. In particular, these diamino derivatives are successfully used for the synthesis of a diaminated product, such as the marine sponge pyrrole-2-aminoimidazole alkaloid ( \pm )-agelastatin A. [79] These diamino cyclopentenone adducts can also be important intermediates if they are treated with different nucleophiles to achieve a second rearrangement, yielding 4-substituted 2-amino-cyclopentenones. Sequential reactions including these rearrangements could produce novel molecular structures with a high degree of complexity, and they seem to be of increasing interest, in the context of biomass valorisation, to generate chemicals from bio-based furan derivatives under industrially relevant reaction conditions [80].

\section{Results}

In our initial experiment, we choose morpholine as an amine substrate to be added to 2-furaldehyde to selectively obtain trans-4,5-dimorpholinocyclopent-2-enone. The studies conducted for the development and optimization of the cyclization rearrangement of furfural and morpholine are presented in Table 1.

The influence of MK10 on the furfural/morpholine system was investigated, and it accomplished the reaction at room temperature (Table 1, entries 1) using $10 \mathrm{wt} \%$ of MK10 with respect to furfural. The corresponding trans-4, 5-dimorpholinocyclopent-2-enone was produced at 55\% yield in $2 \mathrm{hr}$. The gas chromatograpy-mass spectrometry (GC-MS) analysis showed the presence of 2,4-dimorpholinecyclopen-2-enone as a by-product ( $45 \%$ yield).

Although the complete conversion of furfural at room temperature was observed, the confirmation that the procedure could work better was recorded when the same reaction was conducted at higher temperatures, observing a total conversion with better selectivity in only 35 minutes (Table 1, entries 2 and 3). 
Table 1. Optimization of the reaction conditions. ${ }^{\text {a }}$

\begin{tabular}{|c|c|c|c|c|c|}
\hline Entry & MK10 wt (\%) ${ }^{b}$ & $\operatorname{Temp}\left({ }^{\circ} \mathrm{C}\right)$ & Time (min) & Conversion $(\%)^{c}$ & Selectivity (\%) ${ }^{d}$ \\
\hline 1 & 10 & $\mathrm{rt}$ & 120 & 99.9 & 55.0 \\
\hline 2 & 10 & 60 & 35 & 99.9 & 61.1 \\
\hline 3 & 10 & 80 & 35 & 99.9 & 65.3 \\
\hline 4 & 20 & 80 & 35 & 99.9 & 75.0 \\
\hline 5 & 20 & 100 & 20 & 99.9 & 78.3 \\
\hline 6 & - & 100 & 20 & 60.0 & 49.0 \\
\hline $7^{\mathrm{e}}$ & 20 & 80 & 5 & 99.9 & 99.9 \\
\hline $8^{e}$ & 20 & 60 & 5 & 99.9 & 99.9 \\
\hline $9^{e}$ & 20 & 60 & 10 & 99.9 & 99.9 \\
\hline
\end{tabular}

a General reaction conditions: $1 \mathrm{mmol}$ furfural and $2 \mathrm{mmol}$ morpholine were stirred for 5-120 min at different temperatures and different wt (\%) of MK10. ${ }^{\mathrm{b}} \mathrm{wt} \%$ respect to furfural. ${ }^{\mathrm{c}}$ Percentage conversion calculated from the GC-MS data for the conversion of furfural. ${ }^{d}$ Yield (\%) of trans-4,5-dimorpholinocyclopent-2-enone obtained, calculated from GC-MS. The by-product obtained is constituted by 2,4-dimorpholinocyclopent-2-enone. ${ }^{\mathrm{e}}$ Reaction mixture under MW irradiation.

We observed a better conversion with higher selectivity toward the desired product when the amount of catalyst was increased at $20 \mathrm{wt} \%$ when performing the reaction at $80{ }^{\circ} \mathrm{C}$ (Table 1, Entry 4); comparable selectivity was achieved by increasing the temperature (Table 1, Entry 5). Under the same reaction conditions, but in the absence of a catalyst, no complete conversion of furfural, and poor selectivity were observed (Table 1, entry 6). Based on our skills in the development of eco-friendly and selective procedures [54,55], we tested the microwave activation of the reaction, finding that the microwave irradiation at $60{ }^{\circ} \mathrm{C}$ gave the best results in terms of reaction rate and product yield (Table 1, entries 7-9). Surprisingly, we obtained the desired product at $99 \%$ yield in only 5 min at $60{ }^{\circ} \mathrm{C}$ (Table 1 , entry 8 ).

Furthermore, we have evaluated the recyclability of the heterogeneous catalyst in the model reaction. The final reaction mixture, including MK10 and the product, was treated with a green solvent such as ethyl acetate [81]; the catalyst was separated from the solution by filtration, washed with ethyl acetate $(3 \mathrm{~mL})$ four times, and dried in an oven $\left(80^{\circ} \mathrm{C}\right)$ to remove traces of the solvent. Afterwards, the combined organic phases were concentrated under a vacuum, and the crude product was analyzed by GC-MS. The recovered catalyst was used directly for the next run, with the addition of fresh reagents. Thus, the second reaction mixture was subjected again to the above-described procedure, and further reaction cycles were repeated by using the previously recycled MK10.

To demonstrate the efficiency of the catalyst recycled: the MK10 can be recovered and recycled for three sequential cycles in the synthesis of trans-4,5-dimorpholinocyclopent-2-enone, furnishing high yields in every single cycle (Figure 1). The recycling showed the real heterogeneous catalytic nature for the rearrangement reaction, and the stable structure of MK10. 


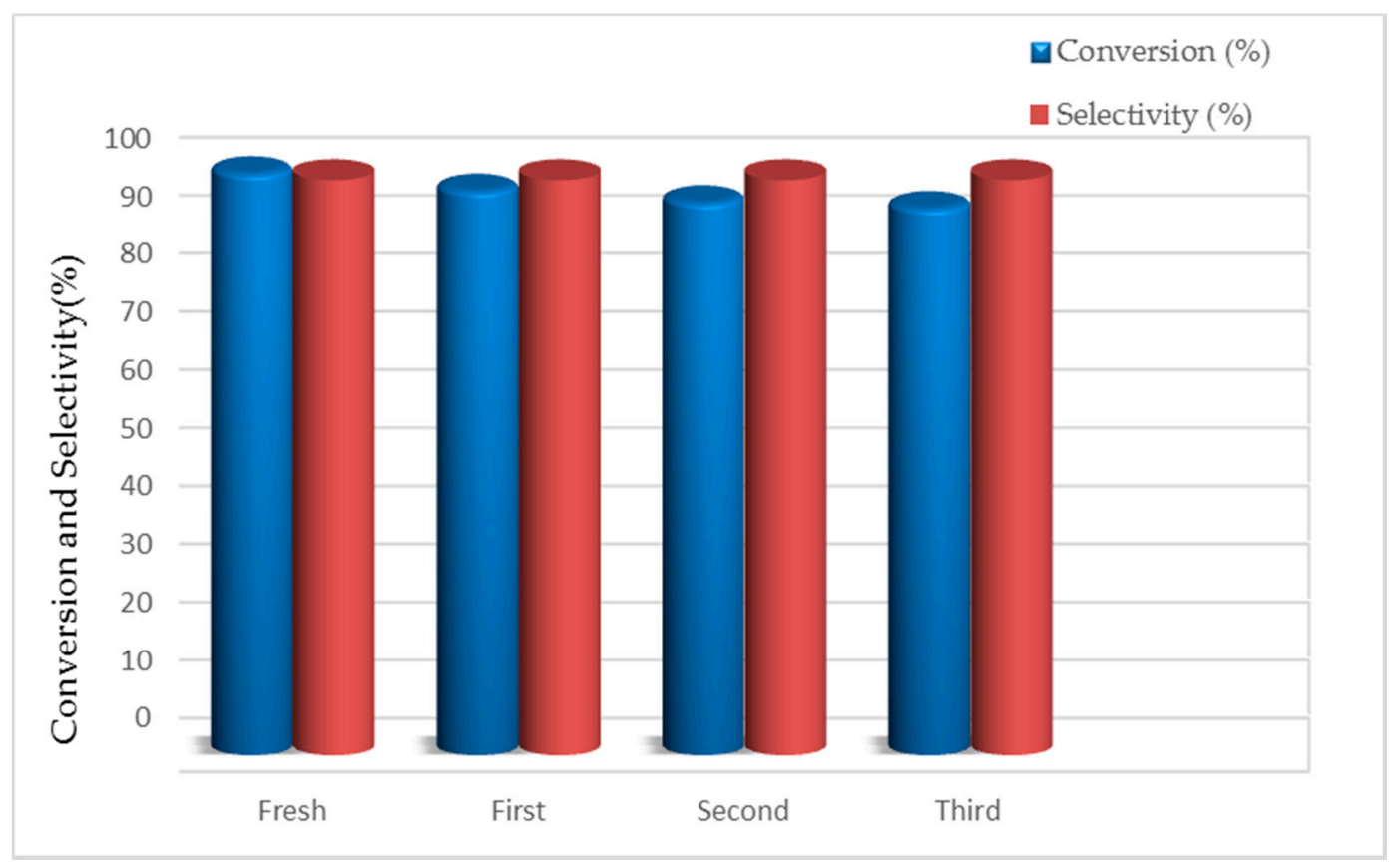

Figure 1. Cycling performance of MK10 in the synthesis of trans-4,5-dimorpholinocyclopen-2-enone under MW irradiation.

Then, to prove the applicability of this eco-friendly process, the model reaction was performed on a scale of $10 \mathrm{mmol}$ of furfural and $20 \mathrm{mmol}$ of morpholine, using the respective amount of MK10. The reaction was accomplished in $10 \mathrm{~min}$ with $98 \%$ isolated yield after simple extraction with ethyl acetate.

At this point, the experimental procedure was applied to different amines to obtain the desired 4,5-diaminocyclopenten-2-enones, and quantitative yields superior to $90 \%$ were obtained in all cases (Table 2). The reaction gave excellent results after the above reported simple workup with the alicyclic (Table 2, Entries 2-4), aliphatic (Table 2, Entries 5-7), and with the aromatic secondary amines (Table 2, entries 8-9); this reaction takes place especially with secondary amines, by the formation of an enamine intermediate as proposed by a previously reported mechanism of reaction $[60,61]$. In the case of primary aliphatic amines, the corresponding imine was observed as the only product (Scheme 1).

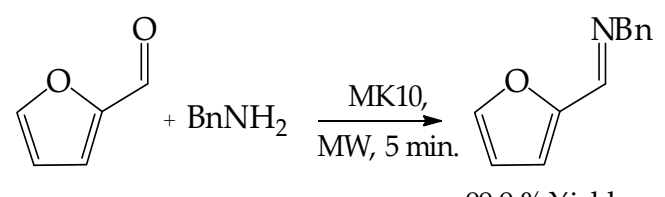

$99.9 \%$ Yield

Scheme 1. Reaction of furfural with $\mathrm{BnNH}_{2}$. 
Table 2. Synthesis of bifunctionalized cyclopentenones. ${ }^{a}$

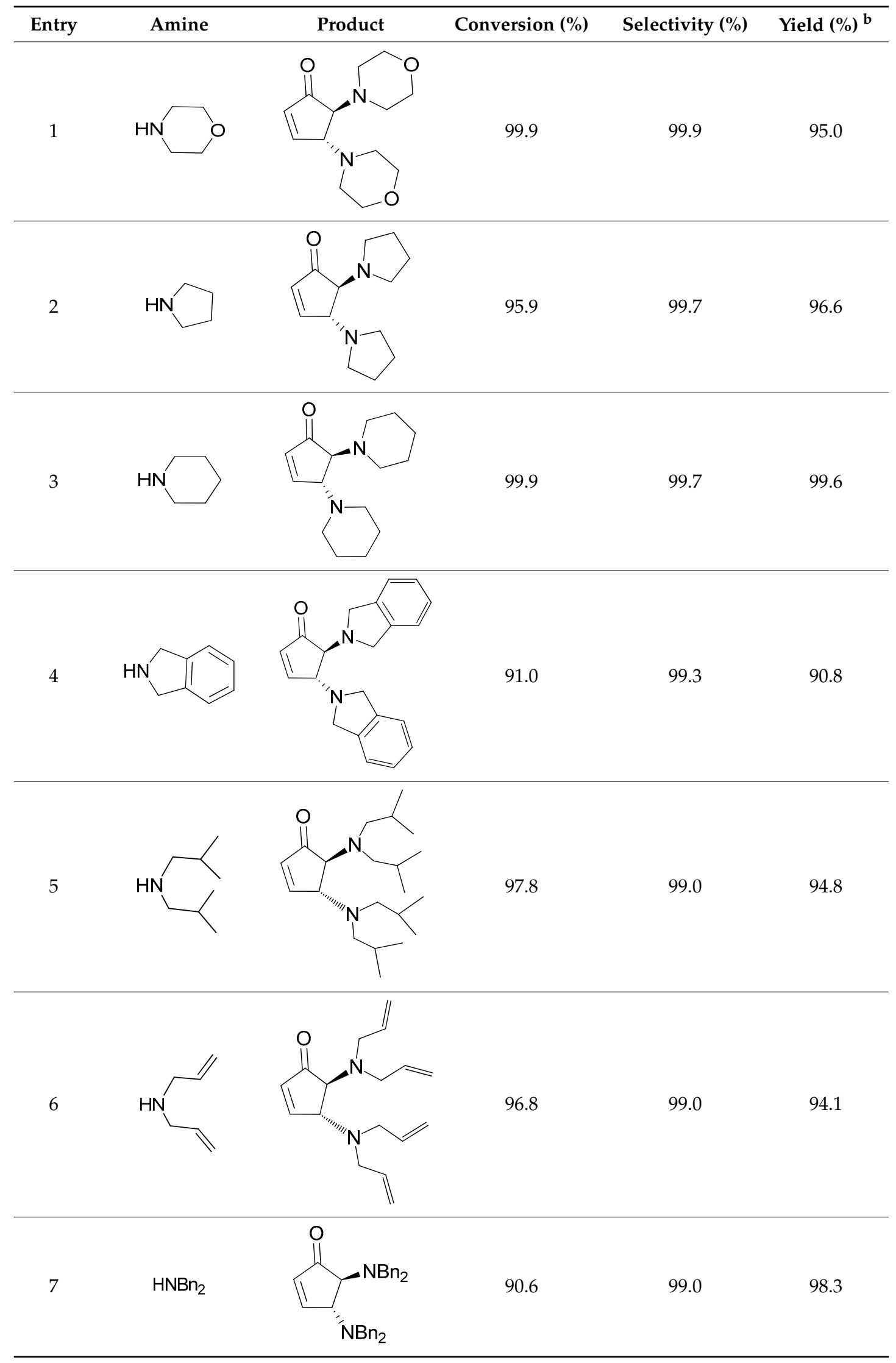


Table 2. Cont.

\begin{tabular}{lllccc}
\hline Entry & Amine & Conversion (\%) & Selectivity (\%) & Yield (\%) ${ }^{\mathbf{b}}$ \\
\hline 8 & & & & & \\
\hline & & & & & \\
\hline
\end{tabular}

${ }^{a}$ General reaction conditions: $1 \mathrm{mmol}$ of furfural and $2 \mathrm{mmol}$ of amine are added to a final concentration of $20 \mathrm{~mol} \%$ to furfural of MK10. The reaction was conducted in a Syntos 3000 microwave oven (Anton-Paar) at $60^{\circ} \mathrm{C}$ for $5 \mathrm{~min}$.

b Percentage yield, estimated from GC-MS data.

2,4-Diamino cyclopent-2-enone, a by-product observed in the cyclization, was obtained at room temperature or in the absence of a catalyst (Table 1 , entries 1 and 6 ) after a long reaction time. As previously observed [57,60], the conversion of 4,5-diamino cyclopentenone to 2,4-diamino cyclopentenone was performed in the presence of an excess of amine. To investigate the catalytic activity of MK10 and its selectivity, we tested the performance of trans-4,5-dimorpholinocyclopent-2-enone in the presence of a small amount of morpholine, to obtain 2,4-dimorpholinocyclopent-2-enone (Scheme 2).

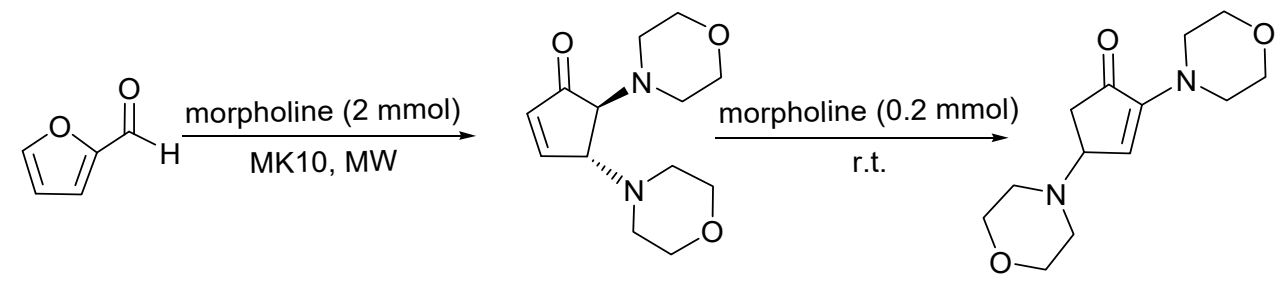

Scheme 2. Synthesis of 2,4-dimorpholinocyclopenten-2-one.

Adding the amine $(0.2 \mathrm{mmol})$ to the reaction mixture at room temperature without microwave irradiation, we observed that the 4,5-dimorpholino cyclopentenone was converted into the respective 2,4-cyclopentenone derivative after only one hour. In fact, the presence of excess amines leads to the formation of an enolic intermediate that successively yields the respective 2,4-cyclopentenone derivative. The mechanism of this reaction was proposed by Lewis and Mulquiney [82].

\section{Materials and Methods}

\subsection{General Methods}

All chemicals and solvents were purchased from common commercial sources, and were used as received without any further purification. Montmorillonite K10 clay (SBET $\left(\mathrm{m}^{2} \cdot \mathrm{g}^{-1}\right): 64.16$. Vtotal $\left(\mathrm{cm}^{3} \cdot \mathrm{g}^{-1}\right)$ : 0.108) obtained from Sigma-Aldrich, has the following chemical composition (wt \%) $\mathrm{SiO}_{2}$ : 67.6; $\mathrm{Al}_{2} \mathrm{O}_{3}$ : 14.6; $\mathrm{Fe}_{2} \mathrm{O}_{3}: 2.9 ; \mathrm{MgO}: 1.8$.

All reactions were monitored by GC-MS. The GC-MS Shimadzu workstation was constituted by a GC 2010 equipped with a QUADREX 007-5MS ( $30 \mathrm{~m} \times 0.25 \mathrm{~mm}, 0.25 \mu \mathrm{m})$ capillary column, operating in "split" mode with $1 \mathrm{~mL} \cdot \mathrm{min}^{-1}$ flow of He as the carrier gas.

${ }^{1} \mathrm{H}-\mathrm{NMR}$ spectra were recorded on a Brüker spectrometer at $300 \mathrm{MHz}$. Chemical shifts are reported in $\delta$ units (ppm), with tretramethylsilane (TMS) as the reference ( $\delta 0.00)$. All coupling 
constants $(J)$ are reported in hertz. Multiplicity is indicated by one or more of the following: $\mathrm{s}$ (singlet), $\mathrm{d}$ (doublet), $\mathrm{t}$ (triplet), $\mathrm{q}$ (quartet), $\mathrm{m}$ (multiplet). ${ }^{13} \mathrm{C}-\mathrm{NMR}$ spectra were recorded on a Brüker spectrometer at $75 \mathrm{MHz}$. Chemical shifts are reported in $\delta$ units $(\mathrm{ppm})$ relative to $\mathrm{CDCl}_{3}(\delta 77.0)$.

MW-assisted reactions were performed on a Synthos 3000 instrument from Anton Paar (Graz, Austria), equipped with a $4 \times 24 \mathrm{MG} 5$ rotor, with an IR probe used for external temperature control.

\subsection{General Experimental Procedure for the Microwave-Assisted Cyclical Rearrangement of Furfural and Amines}

Morpholine (2 mmol) was added to a stirred solution of furfural (1 mmol) and MK10 (20 mg). The resulting mixture was reacted for $5 \mathrm{~min}$ in a Synthos 3000 microwave instrument, fixed at a temperature value of $60^{\circ} \mathrm{C}$ (IR limit).

After completion of the reaction (monitored by GC-MS), the MK10 was separated from the reaction mixture by filtration, and washed with ethyl acetate $(3 \mathrm{~mL})$ four times. The products were isolated after evaporation of the solvent to yield compounds at an efficiency of $90-99 \%$. Spectral data were in accordance with the literature [61].

The reaction of morpholine with furfural was scaled up to grams, using $20 \mathrm{mmol}$ of furfural and $40 \mathrm{mmol}$ of morpholine, with amounts corresponding to MK10. After completion of the reaction and separation of MK10, the product was obtained with a yield of $97 \%$. All the characterization data are available in Supplementary Materials.

\subsection{General Protocol for the Synthesis of 2,4-Diamorpholinecyclopent-2-enones}

After the formation of trans-4,5-dimorpholinocyclopen-2-enone following the reported procedure, we added $0.2 \mathrm{mmol}$ of morpholine to the mixture, and kept the reaction at room temperature for a further hour. After completion, ethyl acetate was added $(3 \mathrm{~mL})$, the catalyst was filtered, and the product was isolated after evaporation of the solvent to afford 2,4-dimorpholinecyclopent-2-enone at $99 \%$ yields. Spectral data were in agreement with the literature [61].

\subsection{Catalyst Recycling}

The MK10 obtained was further evaluated in the cyclization reaction of furfural and morpholine. As shown in Figure 1, after four runs, the selectivity still remained above 99\%, and the conversion was only slightly reduced.

\section{Conclusions}

An effective procedure for the synthesis of trans-4,5-diamino-cyclopent-2-enones has been developed. The reaction showed a high degree of conversion and selectivity.

The use of MK10 under MW irradiation is a valuable method of for the use of a heterogeneous catalyst, as compared to previously reported procedures: the performance does not allow for the use of a solvent, the reaction times are very short, and a greater degree of selectivity in the rearrangement process occurs, thus avoiding the formation of by-products.

Additional advantages of this method are the use of a recyclable heterogeneous catalyst that is stable for the next run. MK10 was reused for three consecutive cycles without any significant loss in catalytic activity for the synthesis of trans-4,5-dimorpholine-cyclopent-2-enones.

Supplementary Materials: The following are available online at http:/ /www.mdpi.com/2073-4344/9/3/301/s1, General Experimental Procedure for Microwave-Assisted Cyclitation rearrangement of furfural and amines.

Author Contributions: M.N. and A.P. conceived and designed the experiments; S.B. and P.C. performed the experiments; A.D.N., M.L.D.G., and M.O. analyzed the data; A.D.N. and A.P. contributed reagents/materials / analysis tools; M.N., M.L.D.G. and A.P. wrote the paper.

Funding: This research received funding from Dipartimento di Scienze della Salute, Università Magna Græcia, Italy.

Conflicts of Interest: The authors declare no conflict of interest. 


\section{References}

1. Thomas, J.M.; Raja, R.; Lewis, D.W. Single-site heterogeneous catalysts. Angew. Chem. Int. Ed. 2005, 44, 6456. [CrossRef]

2. Ballini, R.; Bosica, G.; Carloni, L.; Maggi, R.; Sartori, G. Zeolite HSZ-360 as a new reusable catalyst for the direct acetylation of alcohols and phenols under solventless conditions. Tetrahedron Lett. 1998, 39, 6049-6052. [CrossRef]

3. Procopio, A.; De Luca, G.; Nardi, M.; Oliverio, M.; Paonessa, R. General MW-assisted grafting of MCM-41: Study of the dependence on time dielectric heating and solvent. Green Chem. 2009, 11, 770-773. [CrossRef]

4. Procopio, A.; Cravotto, G.; Oliverio, M.; Costanzo, P.; Nardi, M.; Paonessa, R. An eco-sustainable Erbium(III)-catalysed method for formation/cleavage of O-tert-butoxy carbonates. Green Chem. 2011, 13, 436-443. [CrossRef]

5. Oliverio, M.; Costanzo, P.; Macario, A.; De Luca, G.; Nardi, M.; Procopio, A. A bifuctional heterogeneous catalyst erbium-based: A cooperative route towards C-C bond formation. Molecules 2014, 19, 10218-10229. [CrossRef] [PubMed]

6. Procopio, A.; Das, G.; Nardi, M.; Oliverio, M.; Pasqua, L. A mesoporous Er(III)-MCM-41 catalyst for the cyanosilylation of aldehydes and ketones under solvent-free conditions. ChemSusChem 2008, 1, 916-919. [CrossRef]

7. Mikami, K. Green Reaction Media in Organic Synthesis; Blackwell: Hoboken, NJ, USA, 2005.

8. Nelso, W.M. Green Solvents for Chemistry Perspectives and Practice; Oxford University Press: Oxford, UK, 2004.

9. Lindström, U.M. Stereoselective organic reactions in water. Chem. Rev. 2002, 10, 2751-2772. [CrossRef]

10. Procopio, A.; Gaspari, M.; Nardi, M.; Oliverio, M.; Tagarelli, A.; Sindona, G. Simple and efficient MW-assisted cleavage of acetals and ketals in pure water. Tetrahedron Lett. 2007, 48, 8623-8627. [CrossRef]

11. Procopio, A.; Gaspari, M.; Nardi, M.; Oliverio, M.; Rosati, O. Highly efficient and versatile chemoselective addition of amines to epoxides in water catalyzed by erbium(III) triflate. Tetrahedron Lett. 2008, 49, 2289-2293. [CrossRef]

12. Simon, M.O.; Li, C.J. Green chemistry oriented organic synthesis in water. Chem. Soc. Rev. 2012, 41, 1415-1427. [CrossRef]

13. Oliverio, M.; Costanzo, P.; Paonessa, R.; Nardi, M.; Procopio, A. Catalyst-free tosylation of lipophilic alcohols in water. RSC Adv. 2013, 3, 2548-2552. [CrossRef]

14. Nardi, M.; Herrera Cano, N.; Costanzo, P.; Oliverio, M.; Sindona, G.; Procopio, A. Aqueous MW eco-friendly protocol for amino group protection. RSC Adv. 2015, 5, 18751-18760. [CrossRef]

15. Nardi, M.; Di Gioia, M.L.; Costanzo, P.; De Nino, A.; Maiuolo, L.; Oliverio, M.; Olivito, F.; Procopio, A. Selective acetylation of small biomolecules and their derivatives catalyzed by $\operatorname{Er}(\mathrm{OTf})_{3}$. Catalysts 2017, 7, 269. [CrossRef]

16. Abbott, A.P.; Davies, D.L.; Capper, G.; Rasheed, R.K.; Tambyrajah, V. Ionic Liquids and Their Use As solvents. U.S. Patent 7,183,433, 27 February 2007.

17. Di Gioia, M.L.; Barattucci, A.; Bonaccorsi, P.; Leggio, A.; Minuti, L.; Romio, E.; Temperini, A.; Siciliano, C. Deprotection/reprotection of the amino group in $\alpha$-amino acids and peptides. A one-pot procedure in [Bmim][BF4] ionic liquid. RSC Adv. 2014, 4, 2678-2686. [CrossRef]

18. De Nino, A.; Maiuolo, L.; Merino, P.; Nardi, M.; Procopio, A.; Roca-Lopez, D.; Russo, B.; Algieri, V. Efficient organocatalyst supported on a simple ionic liquid as a recoverable system for the asymmetric diels-alder reaction in the presence of water. ChemCatChem 2015, 7, 830-835. [CrossRef]

19. Di Gioia, M.L.; Gagliardi, A.; Leggio, A.; Leotta, V.; Romio, E.; Liguori, A. N-Urethane protection of amines and amino acids in an ionic liquid. RSC Adv. 2015, 5, 63407-63420. [CrossRef]

20. Di Gioia, M.L.; Costanzo, P.; De Nino, A.; Maiuolo, L.; Nardi, M.; Olivito, F.; Procopio, A. Simple and efficient Fmoc removal in ionic liquid. RSC Adv. 2017, 7, 36482-36491. [CrossRef]

21. Abbott, A.P.; Capper, G.; Davies, D.L.; Rasheed, R.K.; Tambyrajah, V. Novel solvent properties of choline chloride/urea mixtures. Chem. Commun. 2003, 1, 70-71. [CrossRef]

22. Gorke, J.T.; Srienc, F.; Kazlauskas, R.J. Hydrolase-catalyzed biotransformations in deep eutectic solvents. Chem. Commun. 2008, 10, 1235-1237. [CrossRef]

23. Smith, E.L.; Abbott, A.P.; Ryder, K.S. Deep eutectic solvents (DESs) and their applications. Chem. Rev. 2014, 114, 11060-11082. [CrossRef] 
24. Paiva, A.; Craveiro, R.; Aroso, I.; Martins, M.; Reis, R.L.; Duarte, A.R.C. Natural deep eutectic solvents-Solvents for the 21st century. ACS Sustain. Chem. Eng. 2014, 2, 1063-1071. [CrossRef]

25. Virot, M.; Tomao, V.; Ginies, C.; Chemat, F. Total lipid extraction of food using d-limonene as an alternative to n-hexane. Chromatographia 2008, 68, 311-313. [CrossRef]

26. Lapkin, A.; Plucinski, P.K.; Cutler, M. Comparative assessment of technologies for extraction of artemisinin. J. Nat. Prod. 2006, 69, 1653-1664. [CrossRef]

27. Pereira, C.S.M.; Silva, V.M.T.M.; Rodrigues, A.E. Ethyl lactate as a solvent: Properties, applications and production processes. Green Chem. 2011, 13, 2658-2671. [CrossRef]

28. García, J.I.; García-Marín, H.; Pires, E. Glycerol based solvents: Synthesis, properties and applications. Green Chem. 2014, 16, 1007-1033. [CrossRef]

29. Nardi, M.; Oliverio, M.; Costanzo, P.; Sindona, G.; Procopio, A. Eco-friendly stereoselective reduction of $\alpha, \beta$-unsaturated carbonyl compounds by $\operatorname{Er}(\mathrm{OTf})_{3} / \mathrm{NaBH}_{4}$ in 2-MeTHF. Tetrahedron 2015, 71, 1132-1135. [CrossRef]

30. Nardi, M.; Herrera Cano, N.; De Nino, A.; Di Gioia, M.L.; Maiuolo, L.; Oliverio, M.; Santiago, A.; Sorrentino, D.; Procopio, A. An eco-friendly tandem tosylation/ferrier N-glycosylation of amines catalyzed by $\operatorname{Er}(\mathrm{OTf})_{3}$ in 2-MeTHF. Tetrahedron Lett. 2017, 58, 1721-1726. [CrossRef]

31. Jaselnik, M.; Varma, R.S.; Polanca, S.; Kocevar, M. Catalyst-free reactions under solvent-free conditions: Microwave-assisted synthesis of heterocyclic hydrazones below the melting points of neat reactants. Chem. Commun. 2001, 18, 1716-1717. [CrossRef]

32. Procopio, A.; Dalpozzo, R.; De Nino, A.; Maiuolo, L.; Nardi, M.; Russo, B. Synthesis of acetonides from epoxides catalyzed by erbium(III) triflate. Adv. Synth. Catal. 2005, 347, 1447-1450. [CrossRef]

33. Procopio, A.; De Nino, A.; Nardi, M.; Oliverio, M.; Paonessa, R.; Pasceri, R. A new microwave-assisted organocatalytic solvent-free synthesis of optically enriched Michael adducts. Synlett 2010, 12, 1849-1853. [CrossRef]

34. Procopio, A.; Costanzo, P.; Curini, M.; Nardi, M.; Oliverio, M.; Paonessa, R. An eco-sustainable erbium(III) triflate catalyzed formation and cleavage of tert-butyl ethers. Synthesis 2011, 1, 73-78. [CrossRef]

35. Oliverio, M.; Costanzo, P.; Nardi, M.; Calandruccio, C.; Salerno, R.; Procopio, A. Tunable microwave-assisted method for the solvent-free and catalyst-free peracetylation of natural products. Beilstein J. Org. Chem. 2016, 12, 2222-2233. [CrossRef] [PubMed]

36. Maiuolo, L.; Merino, P.; Algieri, V.; Nardi, M.; Di Gioia, M.L.; Russo, B.; Delso, I.; Tallarida, M.A.; De Nino, A. Nitrones and nucleobase-containing spiro-isoxazolidines derived from isatin and indanone: Solvent-free microwave-assisted stereoselective synthesis and theoretical calculations. RSC Adv. 2017, 7, 48980-48988. [CrossRef]

37. Mason, T.J. Sonochemistry: Current uses and future prospects in the chemical and processing industries. Philos. Trans. Royal Soc. Lond. Ser. A 1999, 357, 355-369. [CrossRef]

38. Kappe, O. Controlled microwave heating in modern organic synthesis. Angew. Chem. Int. Ed. 2004, 43, 6250-6284. [CrossRef]

39. Desai, K.R. Green Chemistry Microwave Synthesis, 1st ed.; Himalaya Publication House: New Delhi, India, 2005; p. 20.

40. Cravotto, G.; Cintas, P. The combined use of microwaves and ultrasound: Improved tools in process chemistry and organic synthesis. Chem. Eur. J. 2007, 13, 1902-1909. [CrossRef]

41. Bortolini, O.; D'Agostino, M.; De Nino, A.; Maiuolo, L.; Nardi, M.; Sindona, G. Solvent-free, microwave assisted 1,3-cycloaddition of nitrones with vinyl nucleobases for the synthesis of N,O-nucleosides. Tetrahedron 2008, 64, 8078-8081. [CrossRef]

42. Procopio, A.; Gaspari, M.; Nardi, M.; Oliverio, M.; Romeo, R. MW-assisted Er(OTf $)_{3}$-catalyzed mild cleavage of isopropylidene acetals in Tricky substrates. Tetrahedron Lett. 2008, 49, 1961-1964. [CrossRef]

43. Oliverio, M.; Nardi, M.; Cariati, L.; Vitale, E.; Bonacci, S.; Procopio, A. "On water" mw-assisted synthesis of hydroxytyrosol fatty esters. ACS Sustainable Chem. Eng. 2016, 4, 661-665. [CrossRef]

44. Maiuolo, L.; De Nino, A.; Algieri, V.; Nardi, M. Microwave-assisted 1,3-dipolar cyclo-addition: Recent advances in synthesis of isoxazolidines. Mini Rev. Org. Chem. 2017, 14, 136-142. [CrossRef]

45. Summerton, L.; Sneddon, H.F.; Jones, L.C.; Clark, J.H. Green and Sustainable Medicinal Chemistry: Methods, Tools and Strategies for the 21st Century Pharmaceutical Industry; Royal Society of Chemistry: Cambridge, UK, 2016. 
46. Nardi, M.; Bonacci, S.; De Luca, G.; Maiuolo, J.; Oliverio, M.; Sindona, G.; Procopio, A. Biomimetic synthesis and antioxidant evaluation of 3,4-DHPEA-EDA [2-(3,4-hydroxyphenyl) ethyl (3S,4E)-4-formyl-3(2-oxoethyl)hex-4-enoate]. Food Chem. 2014, 162, 89-93. [CrossRef]

47. Nardi, M.; Bonacci, S.; Cariati, L.; Costanzo, P.; Oliverio, M.; Sindona, G.; Procopio, A. Synthesis and antioxidant evaluation of lipophilic oleuropein aglycone derivatives. Food Funct. 2017, 8, 4684-4692. [CrossRef]

48. Costanzo, P.; Calandruccio, C.; Di Gioia, M.L.; Nardi, M.; Oliverio, M.; Procopio, A. First multicomponent reaction exploiting glycerol carbonate synthesis. J. Clean Prod. 2018, 202, 504-509. [CrossRef]

49. Li, G.; Li, N.; Zheng, M.; Li, S.; Wang, A.; Cong, Y.; Wang, X.; Zhang, T. Industrially scalable and cost-effective synthesis of 1,3-cyclopentanediol with furfuryl alcohol from lignocellulose. Green Chem. 2016, 18, 3607-3613. [CrossRef]

50. Rossi, A.; Kapahi, P.; Natoli, G.; Takahashi, T.; Chen, Y.; Karin, M.; Santoro, M.G. Anti-inflammatory cyclopentenone prostaglandins are direct inhibitors of IkB kinase. Nature 2000, 403, 103-118. [CrossRef] [PubMed]

51. Hsiang, C.H.; Straus, D.S. Cyclopentenone causes cell cycle arrest and represses cyclin D1 promoter activity in MCF-7 breast cancer cells. Oncogene 2002, 21, 2212-2226. [CrossRef] [PubMed]

52. Rozera, C.; Carattoli, A.; De Marco, A.; Amici, C.; Giorgi, C.; Santoro, M.G. Inhibition of HIV-1 replication by cyclopentenone prostaglandins in acutely infected human cells. J. Clin. Investig. 1996, 97, 1795-1803. [CrossRef]

53. Santoro, M.G. Antiviral activity of cyclopentenone prostanoids. Trends Microbiol. 1997, 5, 276-281. [CrossRef]

54. Griffiths, K.; Kumar, P.; Mattock, J.D.; Abdul-Sada, A.; Pitak, M.B.; Coles, S.J.; Navarro, O.; Vargas, A.; Kostakis, G.E. Efficient $\mathrm{Ni}_{2}{ }^{\mathrm{II}} \mathrm{Ln}_{2}{ }^{\mathrm{III}}$ electrocyclization catalysts for the synthesis of trans-4,5-diaminocyclopent2-enones from 2-furaldehyde and primary or secondary amines. Inorg. Chem. 2016, 55, 6988-6994. [CrossRef]

55. Li, S.W.; Batey, R.A. Mild lanthanide (III) catalyzed formation of 4,5-diaminocyclopent-2-enones from 2-furaldehyde and secondary amines: A domino condensation/ring-opening/electrocyclization process. Chem. Commun. 2007, 36, 3759-3761. [CrossRef]

56. Gomes, R.F.A.; Esteves, N.R.; Coelho, J.A.S.; Afonso, C.A.M. Copper (II) triflate as a reusable catalyst for the synthesis of trans-4,5-diamino-cyclopent-2-enones in water. J. Org. Chem. 2018, 83, 7509-7513. [CrossRef] [PubMed]

57. Nunes, J.P.M.; Afonso, C.A.M.; Caddick, S. Synthesis of 2,4-bifunctionalised cyclopentenones from 2-furaldehyde. RSC Adv. 2013, 3, 14975-14978. [CrossRef]

58. Procopio, A.; Costanzo, P.; Curini, M.; Nardi, M.; Oliverio, M.; Sindona, G. Erbium(III) chloride in ethyl lactate as a smart ecofriendly system for efficient and rapid stereoselective synthesis of trans-4,5-diaminocyclopent-2-enones. ACS Sustain. Chem. Eng. 2013, 1, 541-544. [CrossRef]

59. Ramesh, D.; Reddy, T.S.; Narasimhulu, M.; Rajaram, S.; Suryakiran, N.; Mahesh, K.C.; Venkateswarlu, Y. Efficient and rapid stereoselective synthesis of trans-4,5-diaminocyclopent-2-enones by acidic ionic liquid under solvent-free conditions. Chem. Lett. 2009, 38, 586-587.

60. Nardi, M.; Costanzo, P.; De Nino, A.; Di Gioia, M.L.; Olivito, F.; Sindona, G.; Procopio, A. Water excellent solvent for the synthesis of bifunctionalized cyclopentenones from furfural. Green Chem. 2017, 19, 5403-5411. [CrossRef]

61. Di Gioia, M.L.; Nardi, M.; Costanzo, P.; De Nino, A.; Maiuolo, L.; Oliverio, M.; Procopio, A. Biorenewable deep eutectic solvent for selective and scalable conversion of furfural into cyclopentenone derivatives. Molecules 2018, 23, 1891. [CrossRef] [PubMed]

62. Estevão, M.S.; Afonso, C.A.M. Synthesis of trans-4,5-diaminocyclopent-2-enones from furfural catalyzed by Er(III) immobilized on silica. Tetrahedron Lett. 2017, 58, 302-304. [CrossRef]

63. Estevão, M.S.; Martins, R.J.V.; Afonso, C.A.M. Synthesis of trans-4,5-bis-dibenzylaminocyclopent-2-enone from furfural catalyzed by $\mathrm{ErCl}_{3} \cdot 6 \mathrm{H}_{2} \mathrm{O}$. J. Chem. Educ. 2017, 94, 1587-1589. [CrossRef]

64. Deng, Q.; Wang, R. Heterogeneous MOF catalysts for the synthesis of trans-4,5-diaminocyclopent-2-enones from furfural and secondary amines. Catal. Commun. 2019, 120, 11-16. [CrossRef]

65. Bhattacharyya, K.G.; Gupta, S.S. Adsorption of a few heavy metals on natural and modified kaolinite and montmorillonite: A review. Adv. Colloid Interface Sci. 2008, 140, 114-131. [CrossRef]

66. Kaur, N.; Kishore, D. Montmorillonite: An efficient, heterogeneous and green catalyst for organic synthesis. J. Chem. Pharm. Res. 2012, 4, 991-1015. 
67. Kumar, B.S.; Dhakshinamoorthy, A.; Pitchumani, K. K10 montmorillonite clays as environmentally benign catalysts for organic reactions. Catal. Sci. Technol. 2014, 4, 2378-2396. [CrossRef]

68. Hechelski, M.; Ghinet, A.; Brice Louvel, B.; Dufrenoy, P.; Rigo, B.; Daich, A.; Waterlot, C. From conventional lewis acids to heterogeneous montmorillonite K10: Eco-friendly plant-based catalysts used as green lewis acids. ChemSusChem 2018, 11, 1249-1277. [CrossRef]

69. Li, J.-T.; Xing, C.-Y.; Li, T.-S. An efficient and environmentally friendly method for synthesis of arylmethylenemalononitrile catalyzed by Montmorillonite $\mathrm{K} 10-\mathrm{ZnCl}_{2}$ under ultrasound irradiation. J. Chem. Technol. Biotechnol. 2004, 79, 1275-1278. [CrossRef]

70. Nardi, M.; Cozza, A.; Maiuolo, L.; Oliverio, M.; Procopio, A. 1,5-benzoheteroazepines through eco-friendly general condensation reactions. Tetrahedron Lett. 2011, 52, 4827-4834. [CrossRef]

71. Nardi, M.; Cozza, A.; De Nino, A.; Oliverio, M.; Procopio, A. One-pot synthesis of dibenzo[b,e][1,4]diazepin1-ones. Synthesis 2012, 44, 800-804. [CrossRef]

72. Oliverio, M.; Costanzo, P.; Nardi, M.; Rivalta, I.; Procopio, A. Facile ecofriendly synthesis of monastrol and its structural isomers via biginelli reaction. ACS Sustain. Chem. Eng. 2014, 2, 1228-1233. [CrossRef]

73. Herrera Cano, N.; Uranga, J.G.; Nardi, M.; Procopio, A.; Wunderlin, D.A.; Santiago, A.N. Selective and eco-friendly procedures for the synthesis of benzimidazole derivatives. The role of the $\operatorname{Er}(\mathrm{OTf})_{3}$ catalyst in the reaction selectivity. Beilstein J. Org. Chem. 2016, 12, 2410-2419. [CrossRef] [PubMed]

74. De Nino, A.; Maiuolo, L.; Nardi, M.; Pasceri, R.; Procopio, A.; Russo, B. Development of one-pot three component reaction for the synthesis of $N^{\prime}$-aryl- $N$-cyanoformamidines, essential precursors of formamidine pesticides family. Arab. J. Chem. 2016, 9, 32-37. [CrossRef]

75. Costanzo, P.; Bonacci, S.; Cariati, L.; Nardi, M.; Oliverio, M.; Procopio, A. Simple and efficient sustainable semi-synthesis of oleacein [2-(3,4-hydroxyphenyl) ethyl (3S,4E)-4-formyl-3-(2-oxoethyl)hex-4-enoate] as potential additive for edible oils. Food Chem. 2018, 245, 410-414. [CrossRef]

76. Paonessa, R.; Nardi, M.; Di Gioia, M.L.; Olivito, F.; Oliverio, M.; Procopio, A. Eco-friendly synthesis of lipophilic EGCG derivatives and antitumor and antioxidant evaluation. Nat. Prod. Commun. 2018, 9, 1117-1122. [CrossRef]

77. Di Gioia, M.L.; Belsito, E.L.; Leggio, A.; Leotta, V.; Romio, E.; Siciliano, C.; Liguori, A. Reduction of amide carbonyl group and formation of modified amino acids and dipeptides. Tetrahedron Lett. 2015, 56, 2062-2066. [CrossRef]

78. Belsito, E.L.; De Marco, R.; Di Gioia, M.L.; Liguori, A.; Perri, F.; Viscomi, M.C. N-(4-nitrophenylsulfonyl)- and $\mathrm{N}$-(fluorenylmethoxycarbonyl)-N-ethyl amino acid methyl esters-A practical approach. Eur. J. Org. Chem. 2010, 22, 4245-4252. [CrossRef]

79. Duspara, P.A.; Batey, R.A. A short total synthesis of the marine sponge pyrrole-2- aminoimidazole alkaloid ( )-agelastatin, A. Angew. Chem. Int. Ed. 2013, 52, 10862-10866. [CrossRef] [PubMed]

80. Verrier, C.; Moebs-Sanchez, S.; Queneaua, Y.; Popowycz, F. The Piancatelli reaction and its variants: Recent applications to high added-value chemicals and biomass valorization. Org. Biomol. Chem. 2018, 16, 676-687. [CrossRef] [PubMed]

81. Alder, C.M.; Hayler, J.D.; Henderson, R.K.; Redman, A.M.; Shukla, L.; Shuster, L.E.; Sneddon, H.F. Updating and further expanding GSK's solvent sustainability guide. Green Chem. 2016, 18, 3879-3890. [CrossRef]

82. Lewis, K.G.; Mulquiney, C.E. Aspects of the formation and use of stenhouse salts and related compounds. Tetrahedron 1977, 33, 463-475. [CrossRef]

(C) 2019 by the authors. Licensee MDPI, Basel, Switzerland. This article is an open access article distributed under the terms and conditions of the Creative Commons Attribution (CC BY) license (http:/ / creativecommons.org/licenses/by/4.0/). 